\title{
THE INFLUENCE OF BROKEN CABLES ON THE STRUCTURAL BEHAVIOR OF LONG-SPAN CABLE-STAYED BRIDGES
}

\author{
Chin-Sheng Kao \\ Department of Civil Engineering, Tamkang University, Taiwan, R.O.C., csk@mail.tku.edu.tw \\ Chang-Huan Kou \\ Department of Civil Engineering \& Engineering Infomatica, Chung-Hua University, Taiwan, R.O.C
}

Follow this and additional works at: https://jmstt.ntou.edu.tw/journal

Part of the Civil and Environmental Engineering Commons

\section{Recommended Citation}

Kao, Chin-Sheng and Kou, Chang-Huan (2010) "THE INFLUENCE OF BROKEN CABLES ON THE STRUCTURAL

BEHAVIOR OF LONG-SPAN CABLE-STAYED BRIDGES," Journal of Marine Science and Technology. Vol. 18: Iss. 3, Article 9.

DOI: $10.51400 / 2709-6998.1885$

Available at: https://jmstt.ntou.edu.tw/journal/vol18/iss3/9

This Research Article is brought to you for free and open access by Journal of Marine Science and Technology. It has been accepted for inclusion in Journal of Marine Science and Technology by an authorized editor of Journal of Marine Science and Technology. 


\title{
THE INFLUENCE OF BROKEN CABLES ON THE STRUCTURAL BEHAVIOR OF LONG-SPAN CABLE-STAYED BRIDGES
}

\author{
Chin-Sheng Kao* and Chang-Huan Kou**
}

Key words: cable-stayed bridge, broken cable, structural behavior, ultimate load-bearing capacity.

\section{ABSTRACT}

The influence of broken cables on the structural behavior of long-span cable-stayed bridges is examined considering all the nonlinear characteristics of a long-span cable-stayed bridge. The results show the influences of the broken cable on the structural behavior, such as the internal force, displacement, and the ultimate load-bearing capacity, are clear when an outside cable breaks. The results of the present study should assist in deciding when to replace cables in long-span cablestayed bridges.

\section{INTRODUCTION}

In the last half-century, many cable-stayed bridges have been built or are under construction all over the world. The rapid progress of this type of bridge is mainly due to the development of computer technology, high-strength materials and construction technology $[1,2,5,9]$. Because of its aesthetic appeal, economics and ease of erection, the cable-stayed bridge is considered to be most suitable for medium- to long-span bridges with spans ranging from 200 to about 1000 $\mathrm{m}[2,5]$.

The cables sustaining the cable-stayed bridge may break due to a collision resulting from a car accident, lack of maintenance over a long period of time, or excessive corrosion of the connection. It is also possible similar behavior may occur due to loosening a cable before replacing it. Therefore, it is worth studying whether a slender long-span cable-stayed bridge would cause any safety problems for these reasons; especially when there have been real cases of structural damage resulting from cables breaking due to corrosion [14]. Further study of this issue has therefore been undertaken.

Paper submitted 05/01/09; revised 06/15/09; accepted 06/23/09. Author for correspondence: Chin-Sheng Kao (e-mail: csk@mail.tku.edu.tw). *Department of Civil Engineering, Tamkang University, Taiwan, R.O.C.

**Department of Civil Engineering \& Engineering Infomatica, Chung-Hua University, Taiwan, R.O.C.
In fact, the longer the span length, the more flexible is the bridge structural system. Because of their huge size and complicated nonlinear structural behaviors, the analysis of cable-stayed bridges is much more complicated than conventional bridges, such as truss and girder bridges. The sources of nonlinearity in cable-stayed bridges mainly include: the cable sag, beam-column and large deflection effects. Many studies on this type of bridge have been carried out in the last half-century. Tang suggested using the iteration method to analyze the nonlinear effects on a cable-stayed bridge [12]. Lazar et al used slanted prestressed cables to resist the external load, and perform stress analysis with the balanced load method [8]. Tang used a methodology proposed by Ernst [3], based on the "equivalent Young's modulus (Eeq) of cables" and on considering the beam-column effect, to carry out a static analysis for a cable-stayed bridge [13]. Podolny and Scalzi proposed a stiffness method as the basis for the static analysis of cable-stayed bridges. They found most nonlinear behaviors of cable-stayed bridges were caused by the sagging effect in the cable, and this nonlinear effect must be considered and incorporated into the initial dead load analysis [11]. Fleming derived a stable function under the influence of the beam element to modify the axial stiffness, the lateral stiffness and the bending stiffness, to establish a structural analysis model of cable-stayed bridges using the finite element analysis concept [4]. Hegab analyzed the structure of a three- dimensional double-cable plane cable-stayed bridge using the energy method with an incremental iteration approach, and also considering the torsion effect $[6,7]$. Nazmy and Abdel-Ghaffar conducted a nonlinear static analysis of a three-dimensional cable-stayed bridge by applying the finite element approach. They also performed the analysis using incremental iteration of the loading and the tangent stiffness matrix of the structure, considering all the potential nonlinear behaviors. Many studies of this type of bridge have been carried out, but only a few papers have analyzed the effect of broken cables on cablestayed bridges [10].

In the present study, the following approaches or methodologies were employed: the updated Lagrangian formulation was used to treat for the nonlinear large displacement effect produced by the entire cable-stayed bridge; the curved cable element was considered for the sagging cable in the cable- 
stayed bridge; the enclosed box girder element was investigated by considering the coupling of the axial force with the bending moment for directly assessing the beam-column effect of the main girder and the tower; the Prandtl-Reuss incremental theory and the Von Mises yielding criterion were used to deal with the material nonlinear effects before ultimate failure of the cable-stayed bridge was reached; and lastly, displacement control was used to solve the equilibrium equation of the nonlinear system.

\section{THEORIES AND METHODS}

\section{Basic Assumptions}

(a) Let the stress in the direction of the slab thickness be zero and the cross-section be plane and remain plane before and after yielding.

(b) Localized bucking of steel plates is not considered.

(c) Both the normal stress caused by warping deformation and the shearing stress caused by bending deformation are ignored.

(d) The material is an ideal elasto-plastic material.

(e) The Prandtl-Reuss incremental theory and the Von-Mises yielding criterion hold in the plastic state.

(f) The shear flow in the elasto-plastic state in the enclosed cross-section remains constant.

\section{Incremental Stiffness Matrix of the Beam-Column Element}

Based on the Von Mises yielding criterion, the equivalent stress can be expressed as:

$$
\bar{\sigma}=\sqrt{\sigma^{2}+3 \tau^{2}}=\sigma_{y}
$$

where $\sigma_{y}$ stands for the axial yielding stress.

Based on the Prandtl-Reuss incremental theory, the composition rule of normal stress increment $\Delta \sigma$ and shear stress increment $\Delta \tau$ of an ideal elasto-plastic element can be expressed as:

$$
\left\{\begin{array}{c}
\Delta \sigma \\
\Delta \tau
\end{array}\right\}=\left[D_{e p}\right]\left\{\begin{array}{c}
\Delta \varepsilon_{z}^{L} \\
\Delta \gamma
\end{array}\right\}=\left[\begin{array}{cc}
D_{1} & D_{3} \\
D_{3} & D_{2}
\end{array}\right]\left\{\begin{array}{c}
\Delta \varepsilon_{z}^{L} \\
\Delta \gamma
\end{array}\right\}
$$

In the elastic zone:

$$
[D]=\left[D_{e}\right]=\left[\begin{array}{cc}
D_{1} & -D_{3} \\
-D_{3} & D_{2}
\end{array}\right]=\left[\begin{array}{cc}
E & 0 \\
0 & G
\end{array}\right]
$$

and in the plastic zone:

$$
[D]=\left[D_{P}\right]=\left[\begin{array}{cc}
D_{1} & -D_{3} \\
-D_{3} & D_{2}
\end{array}\right]=\left[\begin{array}{cc}
9 E G \pi^{2} / B & 3 E G \sigma \tau / B \\
3 E G \sigma \tau / B & E G \pi^{2} / B
\end{array}\right]
$$

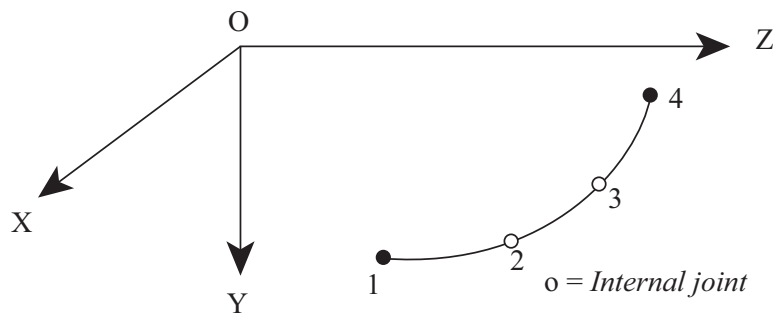

Fig. 1 Cable element.

Where $B=E \sigma^{2}+9 G \sigma^{2}$; the linear axial strain increment $\Delta \varepsilon^{L}$ can be expressed from the updated Lagrangian formulation; the shear strain increment $\Delta \gamma$ can be calculated by the thin-wall beam theory; $E$ is Young's modulus; $G$ is the shear modulus and the elasto-plastic matrix of the incremental theory can be expressed as:

$$
\left[D_{e p}\right]=\left[D_{e}\right]-\left[D_{p}\right]
$$

By applying the updated Largrangian formulation and the principle of virtual work, the equilibrium equation becomes:

$$
\left(\left[K_{e p}\right]^{e}+\left[K_{G}\right]^{e}\right)\{\Delta u\}^{e}=\{\Delta P\}^{e}
$$

Where $\left[K_{e p}\right]^{e}$ and $\left[K_{G}\right]^{e}$ are the elasto-plastic stiffness and geometrical stiffness matrix respectively. They can be expressed as:

$$
\begin{aligned}
& {\left[K_{e p}\right]^{e}=\int_{V}\left[B_{L}\right]^{T}\left[D_{e p}\right]\left[B_{L}\right] d v} \\
& {\left[K_{G}\right]^{e}=\int_{v}[G]^{T}\left[\sigma^{0}\right][G] d v}
\end{aligned}
$$

where $\left[B_{L}\right]$ and $[G]$ are the relative matrixes between strain and displacement, and $\left[\sigma^{0}\right]$ is the initial stress matrix.

\section{Incremental Stiffness Matrix of the Cable Element}

For a cable element, the present study employed a curve element with $m$ nodes (see Fig. 1). Its incremental displacement and the coordinate vector of the internal element can be expressed as:

$$
\left\{\begin{array}{c}
\Delta u(s)=[N(s)]\left[\Delta u_{1}, \cdots, \Delta u_{m}\right]^{T}=[N] \Delta u^{e} \\
X(s)=[N(s)]\left[X_{1}, \cdots, X_{m}\right]^{T}=[N] X^{e}
\end{array}\right.
$$

where $X(s)$ and $X^{e}$ are the coordinate vectors of the internal element and the internal node respectively; $\Delta u^{e}$ is the increment of the nodal displacement vector, and $[N]$ is a shape function matrix [11].

After considering curvature, the linear strain increment $\Delta \varepsilon^{L}$ 
of the flexible cable and its nonlinear strain increment $\Delta \varepsilon^{N}$ can be expressed as:

$$
\begin{gathered}
\Delta \varepsilon^{L}=\frac{\partial \Delta u_{s}}{\partial s}-\frac{\Delta u_{t}}{R} \\
\Delta \varepsilon^{N}=\frac{1}{2}\left[\left(\frac{\partial \Delta u_{n}}{\partial s}\right)^{2}+\left(\frac{\partial \Delta u_{t}}{\partial s}+\frac{\Delta u_{s}}{R}\right)^{2}+\left(\frac{\partial \Delta u_{s}}{\partial s}-\frac{\Delta u_{t}}{R}\right)^{2}\right]
\end{gathered}
$$

Thus the $\left[B_{L}\right]$ and $[G]$ matrixes are respectively:

$$
\begin{gathered}
{\left[B_{L}\right]=\frac{\partial^{2} X^{T}}{\partial s^{2}}[N]+\frac{1}{J} e_{S}^{T} \frac{\partial[N]}{\partial \xi}-} \\
\sqrt{\left(\partial^{2} X / \partial s^{2}\right)^{2}+\left(\partial^{2} Y / \partial s^{2}\right)^{2}+\left(\partial^{2} Z / \partial s^{2}\right)^{2}} e_{n}^{T}[N] \\
{[G]=\left[\frac{1}{J} \frac{\partial N_{1}}{\partial \xi}[e]^{T}+N_{1} \frac{\partial[e]^{T}}{\partial s}+\frac{N_{1}}{r}\left[e^{*}\right], \cdots\right.} \\
\left.\frac{1}{J} \frac{\partial N_{n}}{\partial \xi}[e]^{T}+N_{n} \frac{\partial[e]^{T}}{\partial s}+\frac{N_{n}}{r}\left[e^{*}\right]\right]
\end{gathered}
$$

where $R$ is the radius of curvature of the cable; $J$ is the Jacobian matrix; $N_{1}$ and $N_{n}$ are the complementary function of the Lagrangian; $\xi$ is the natural coordinate of the cable element; and $r$ is a position vector of the cable.

$$
\begin{gathered}
{[e]=\left[\begin{array}{lll}
\mathbf{e}_{n} & \mathbf{e}_{t} & \mathbf{e}_{s}
\end{array}\right]=\left[\begin{array}{lll}
e_{11} & e_{12} & e_{13} \\
e_{21} & e_{22} & e_{23} \\
e_{31} & e_{32} & e_{33}
\end{array}\right]} \\
{\left[e^{*}\right]=\left[\begin{array}{rrr}
e_{13} & e_{23} & e_{33} \\
0 & 0 & 0 \\
-e_{11} & -e_{21} & -e_{31}
\end{array}\right]}
\end{gathered}
$$

The following formula can then be used to attain the incremental stiffness matrix of the cable element:

$$
\begin{gathered}
{\left[K_{e}\right]=\int_{l}\left[B_{L}\right]^{T} E_{c} A_{c}\left[B_{L}\right] d s} \\
{\left[K_{g}\right]=\int_{l}[G]^{T} T^{0}[G] d s}
\end{gathered}
$$

where $E_{C} A_{C}$ is the axial rigidity of the cable, and $T^{0}$ is the initial cable force.

\section{Solving the Nonlinear Equation}

The Newton-Raphson iteration method and arch-length method were employed to solve the equilibrium equation of the system.

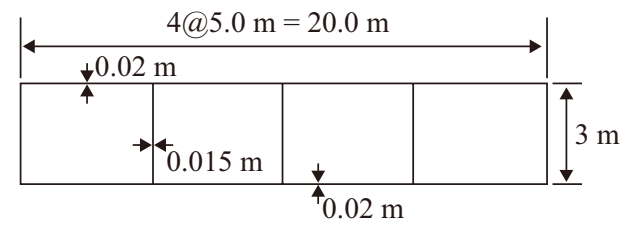

(a) Girder cross-section

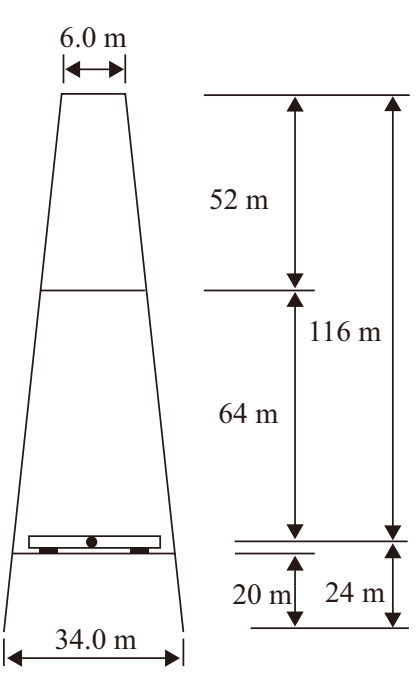

(b) Shape of tower

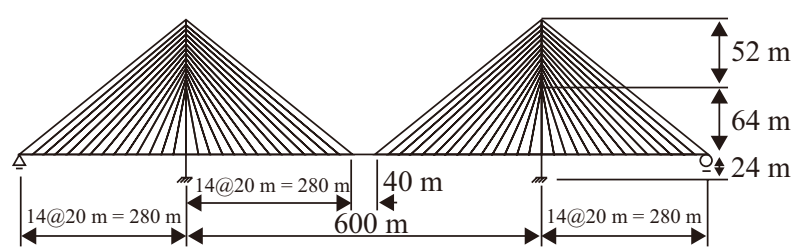

(d) Side view of a cable-stayed bridge

\section{STRUCTURAL ANALYSIS}

\section{Basic Data}

The present analysis was performed for a symmetrical, fan-shaped, double-cable-plane, double-tower three-span cable-stayed bridge. The bridge has a total span of $1160 \mathrm{~m}$, including a $600 \mathrm{~m}$ center-span and two side-spans of $280 \mathrm{~m}$ each. The A-shape tower situated in the bridge is $140 \mathrm{~m}$ high, with lateral diaphragm beams provided at the very top of the tower, and at $52 \mathrm{~m}$ and $120 \mathrm{~m}$ respectively from the top of the tower. The upper part of the tower, from the top of the tower to the $52 \mathrm{~m}$ diaphragm beams, is the anchoring zone of the cables. 112 cables are attached to the bridge; 14 pairs of cables are allocated on each side of the two towers. The spacing of the cable anchors on the tower is $4 \mathrm{~m}$; and the cable spacing on the girder is $20 \mathrm{~m}$. The constraint condition of the tower foundation is set as fixed joints, while the joints between the cable and the girder are hinged. The intersections of the tower and the girder are simulated with hinge joints. Figure 2 and Table 1 show the analyzed model and the cross-sectional parameters 
Table 1. Cross-sectional parameters of cable-stayed bridge.

\begin{tabular}{|c|c|c|c|c|}
\hline & $A\left(\mathrm{~m}^{2}\right)$ & $I_{X}\left(\mathrm{~m}^{4}\right)$ & $I_{Y}\left(\mathrm{~m}^{4}\right)$ & $J\left(\mathrm{~m}^{4}\right)^{*}$ \\
\hline Girder & 1.025 & 1.9688 & 37.917 & 3.888 \\
\hline Tower & 0.960 & 4.3333 & 7.1867 & 6.125 \\
\hline Cable & \multicolumn{5}{|c|}{$0.020699\left(\mathrm{~m}^{2}\right) /$ Single cable } \\
\hline
\end{tabular}

*Neglecting the longitudinal stiffener

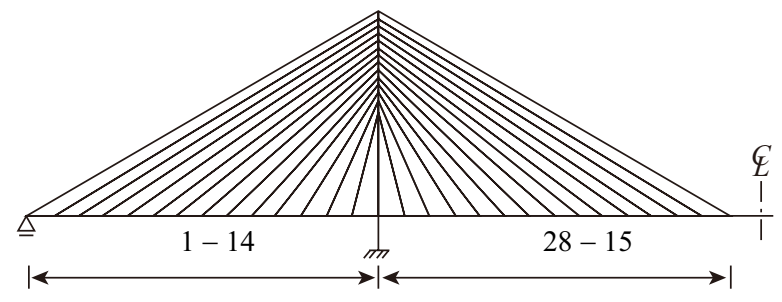

Fig. 3. Cable numbering and location.

of the girder, tower and cable. In the simulation, the girder and tower were made of SM490Y (JIS) steel, and the cable wires were made of ST1570 (JIS) steel.

The object being considered is a two-tower, symmetricalspan, cable-stayed bridge. Broken cables on only one tower of the bridge were analyzed. Figure 3 shows the cable pairs 1-14 on the side-span and the cable pairs 15-28 on the center-span were considered to break one by one each time for analysis and comparison.

The static mechanical behavior of the cable-stayed bridge was investigated, both in the initial state and in the completed bridge state, and the mechanical behavior before and after the cable broke was also compared.

\section{Analysis Models}

In the initial state analysis, the anchor end on the girder of the stayed-cable was assumed to be a rigid support, as shown in Fig. 4. The vertical reaction of each rigid support resulting from dead load $W_{G}$ of the superstructure was then calculated according to the continuous beam theory. This reacting force was taken as the vertical component force of the initial cable force. Using this rigid-support theory, the initial cable force in the center-span can be calculated. The cable force in the sidespan can be derived from the equilibrium condition of its horizontal components on both sides of the tower.

In the completed bridge state analysis, the 3-D frame incorporating a structural model of the curved cable was used. Besides the dead load $W_{G}$ derived by the following equation, a live load equivalent to the dead load was included to analyze the load-bearing capacity.

$$
W_{G}=\left(1.4 \times A_{s}\right) \times \gamma_{s}+70.0
$$

Where 1.4 is the multiplier for considering the weights of other components, $A_{s}$ is the cross-section area of the girder; $\gamma_{s}$ is the

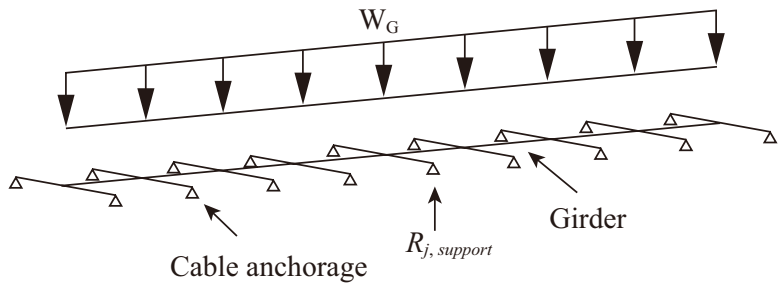

Fig. 4. Structural model of continuous beam with rigid supports.

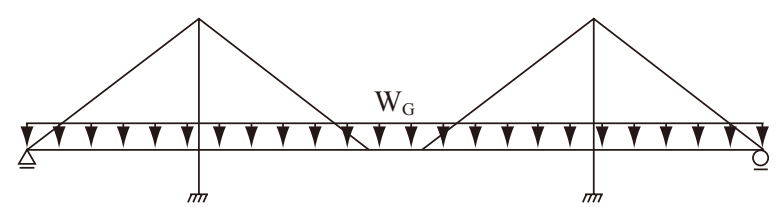

Fig. 5. Schematic diagram of loading.

unit weight of the steel, and $70.0(\mathrm{kN} / \mathrm{m})$ is the extra dead load including the slab, pavement, rails, curbs, etc.

The ultimate strength analysis used the same structural model as that used for the completed bridge state analysis. A live load, which was $(\alpha-1)$ times the dead load was used (see Fig. 5). Here, the value of $\alpha$ is gradually increased from zero during the analysis, using the incremental displacement approach or arc-length approach for the nonlinear convergence calculation. The axial displacement of the girder end was used as the increment parameter for making the judgment.

\section{Results of Analysis}

(a) The cable forces increased significantly in the cables near the 1st and 15th pairs after the 1st pair of cables in the completed bridge state had broken (see Fig. 6). A slight decrease in the axial force in the left-hand side girder and a slight increase of axial force in the right-hand side girder were observed (see Fig. 7). The bending moment in the left-hand side-span was significantly diminished, becoming a negative moment, while the bending moment of the center-span girder was significantly increased (see Fig. 8). There was a slight decrease in the axial force in the tower (see Fig. 9). The bending moment in the tower increased significantly (see Fig. 10). The side-span girder was appreciably lifted (see Fig. 11). A significant increase in tower deformation was observed (see Fig. 12).

(b) In the ultimate state, the plastic hinge of the girder occurs within the range of joints where the 6th and 10th pairs of cables are anchored and where the 14th and 28th pairs of cables are anchored (see Fig. 13).

(c) In the completed bridge state, the sag at the center of the girder reached its maximum value of $62.43 \%$ when the 1 st pair of the outermost cables broke (see Table 2).

(d) The uplift deformation of the girder at different positions may be attributed to the redistribution of cable forces resulting from the cables breaking at different positions, as shown in Table 3. 


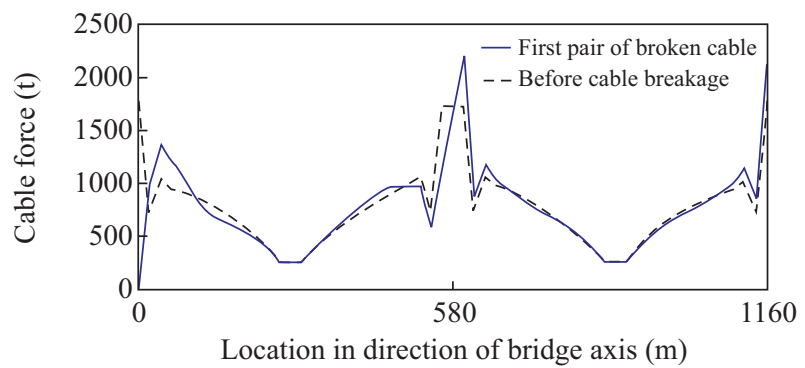

Fig. 6. Distribution of cable force in completed bridge state.

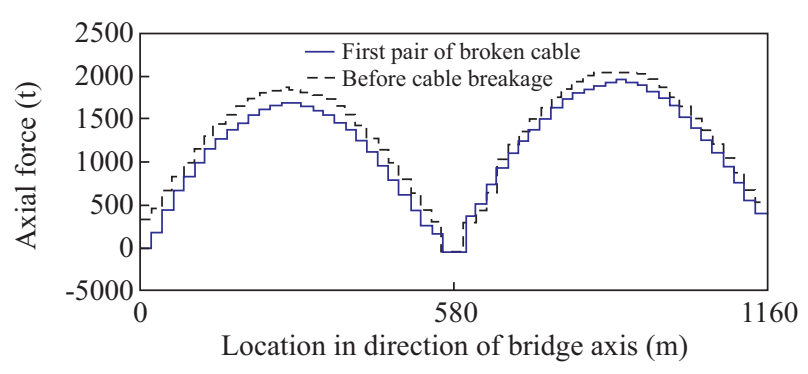

Fig. 7. Distribution of girder axial force in completed bridge state.

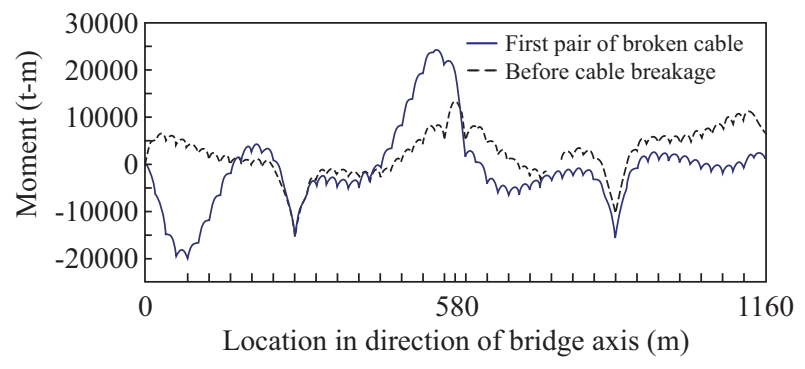

Fig. 8. Distribution of girder bending moment in completed bridge state.

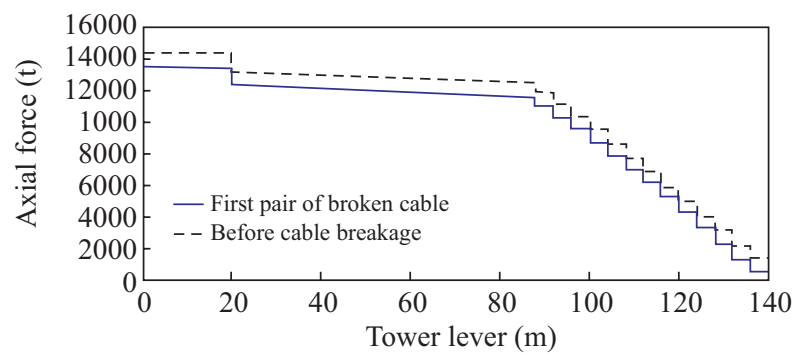

Fig. 9. Distribution of tower axial force in completed bridge state.

(e) There was a $28 \%$ increase in deformation occurring in the tower at the far end of the bridge axis when the 3rd pair of cables broke (see Table 4). In Table 4, the "“" sign denotes tower displacement towards the side span.

(f) There were $10-40 \%$ increases in cable force for cables located near a broken cable (see Tables 5 and 6).

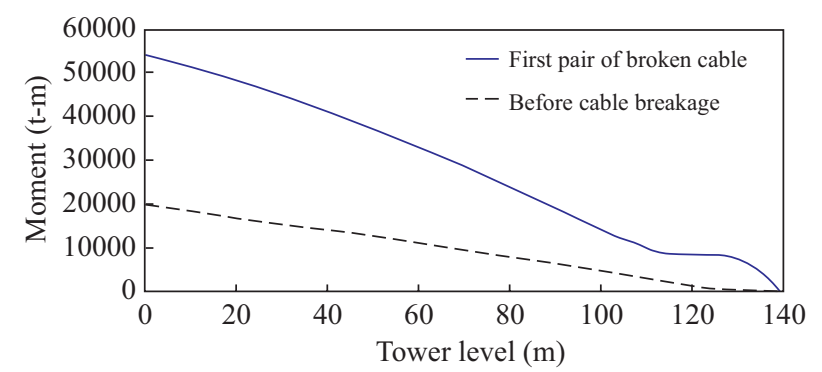

Fig. 10. Distribution of tower bending moment in completed bridge state.

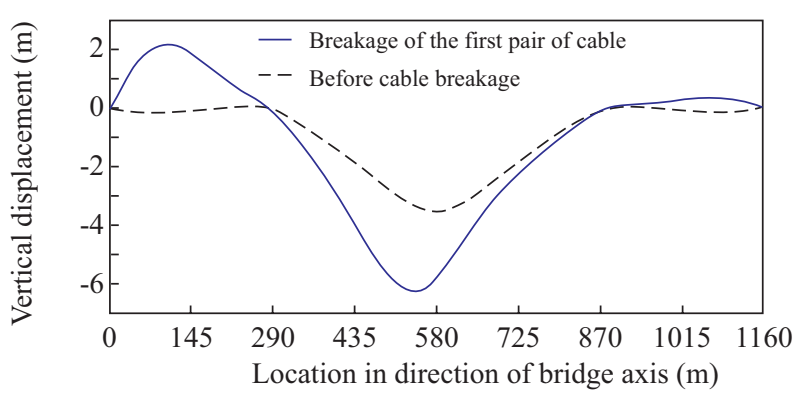

Fig. 11. Diagram of Girder Deformation.

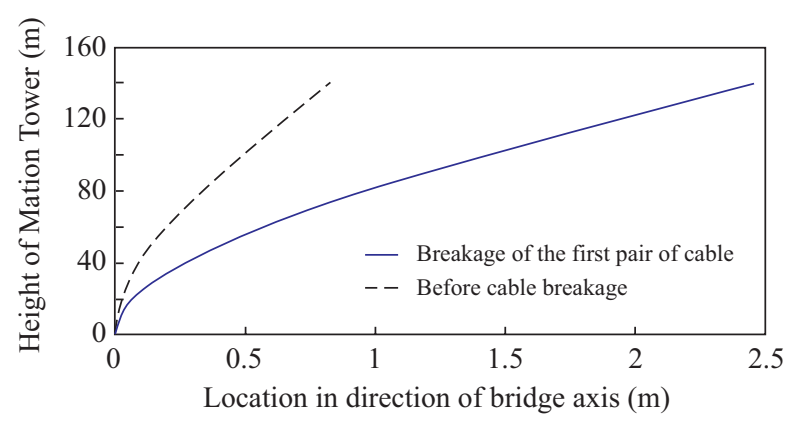

Fig. 12. Diagram of Tower Deformation.

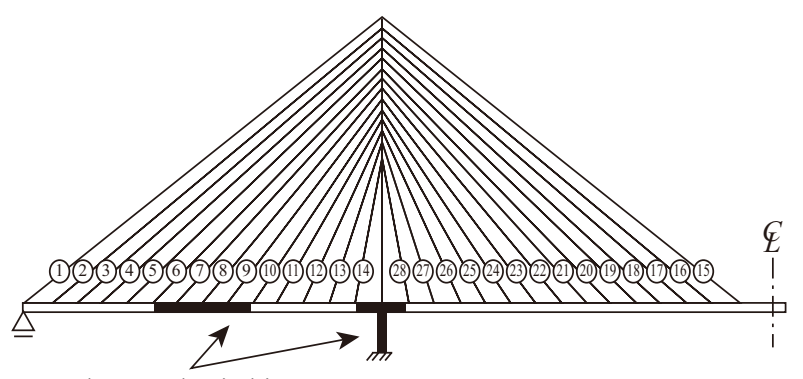

Where a plastic hinge occurs

Fig. 13. Location of ultimate plastic hinge of cable-stayed bridge.

(g) There was roughly a 58\% increase in the total girder stress when the 15th pair of cables broke (see Table 7). This stress is calculated by $[\sigma] *=\frac{P_{z}}{A}+\frac{M_{x} y}{I_{x x}}$. 
Table 2. Deviation of main girder central sag resulting from broken cable at different locations.

\begin{tabular}{|c|c|c|c|c|c|}
\hline \multicolumn{3}{|c|}{ Side span } & \multicolumn{3}{|c|}{ Center span } \\
\hline $\begin{array}{l}\text { No. of broken } \\
\text { cable }\end{array}$ & $\begin{array}{l}\text { Displacement, center of } \\
\text { girder of center } \operatorname{span}(\mathrm{m})\end{array}$ & $\begin{array}{l}\text { Deviation of the } \\
\text { displacement }(\%)\end{array}$ & $\begin{array}{l}\text { No. of broken } \\
\text { cable }\end{array}$ & $\begin{array}{l}\text { Displacement, center of } \\
\text { girder of center } \operatorname{span}(\mathrm{m})\end{array}$ & $\begin{array}{l}\text { Deviation of the } \\
\text { displacement }(\%)\end{array}$ \\
\hline 1 & 5.8266 & 62.43 & 15 & 5.1222 & 42.79 \\
\hline 2 & 3.9085 & 8.96 & 16 & 3.8991 & 8.69 \\
\hline 3 & 3.8909 & 8.46 & 17 & 3.9523 & 10.18 \\
\hline 4 & 3.7270 & 3.90 & 18 & 3.8004 & 5.94 \\
\hline 5 & 3.6296 & 1.18 & 19 & 3.6998 & 3.14 \\
\hline 6 & 3.5742 & -0.36 & 20 & 3.6227 & 0.99 \\
\hline 7 & 3.5516 & -0.99 & 21 & 3.5770 & -0.28 \\
\hline 8 & 3.5481 & -1.09 & 22 & 3.5516 & -0.99 \\
\hline 9 & 3.5592 & -0.78 & 23 & 3.5521 & -0.98 \\
\hline 10 & 3.5722 & -0.42 & 24 & 3.5594 & -0.78 \\
\hline 11 & 3.5803 & -0.19 & 25 & 3.5686 & -0.54 \\
\hline 12 & 3.5858 & -0.04 & 26 & 3.5757 & -0.32 \\
\hline 13 & 3.5931 & 0.16 & 27 & 3.5860 & -0.03 \\
\hline 14 & 3.5869 & -0.01 & 28 & 3.5858 & -0.04 \\
\hline & & \multicolumn{2}{|c|}{$\begin{array}{c}\text { Displacement, center of girder of } \\
\text { Center-span with no broken cable }(\mathrm{m})\end{array}$} & 3.5872 & \\
\hline
\end{tabular}

Table 3. Uplifted deformation of girder resulted from broken cable at different locations.

\begin{tabular}{|c|c|c|c|}
\hline $\begin{array}{c}\text { No. of broken } \\
\text { cable }\end{array}$ & $\begin{array}{c}\text { Joint number of girder with } \\
\text { increased deformation }\end{array}$ & $\begin{array}{c}\text { No. of broken } \\
\text { cable }\end{array}$ & $\begin{array}{c}\text { Joint number of girder with } \\
\text { increased deformation }\end{array}$ \\
\hline 1 & $1-4$ & 15 & $19-28$ \\
2 & $2-14$ & 16 & $20-28$ \\
3 & $6-14$ & 17 & $22-28$ \\
4 & $8-14$ & 18 & $23-28$ \\
5 & $10-14$ & 19 & $1-11,25-28$ \\
6 & $1,10-14,15-25$ & 20 & $1-12,27,28$ \\
7 & $1,13,14,15-27$ & 21 & $1-12,15,28$ \\
9 & $1,14,-15-28$ & 22 & $1-14,15-17$ \\
10 & $1,15-28$ & 23 & $2-14,15-18$ \\
11 & $1,2,15-28$ & 25 & $2-14,15-19$ \\
13 & $1-5,15-28$ & 26 & $10-14,15-21$ \\
\hline
\end{tabular}

Table 4. Deviation of top-of-tower displacement resulted from broken cable at different locations.

\begin{tabular}{|c|c|c|c|c|c|}
\hline \multicolumn{3}{|c|}{ Side span } & \multicolumn{3}{|c|}{ Center span } \\
\hline $\begin{array}{l}\text { No. } \\
\text { of broken cable }\end{array}$ & $\begin{array}{c}\text { Top-of-tower } \\
\text { Displacement } \\
\text { (after breakage, m) }\end{array}$ & $\begin{array}{c}\text { Influence of } \\
\text { top-of-tower } \\
\text { displacement }(\%)\end{array}$ & $\begin{array}{l}\text { No. } \\
\text { of broken cable }\end{array}$ & $\begin{array}{c}\text { Top-of-tower } \\
\text { Displacement } \\
\text { (after breakage, m) }\end{array}$ & $\begin{array}{c}\text { Influence of } \\
\text { top-of-tower } \\
\text { displacement }(\%)\end{array}$ \\
\hline 1 & 2.4551 & 196.94 & 15 & 0.3949 & -52.24 \\
\hline 2 & 1.0580 & 27.96 & 16 & 0.7586 & -8.25 \\
\hline 3 & 1.0423 & 26.06 & 17 & 0.7826 & -5.35 \\
\hline 4 & 0.9240 & 11.75 & 18 & 0.8225 & -0.52 \\
\hline 5 & 0.8552 & 3.43 & 19 & 0.8414 & 1.77 \\
\hline 6 & 0.8156 & -1.35 & 20 & 0.8463 & 2.36 \\
\hline 7 & 0.8004 & -3.20 & 21 & 0.8431 & 1.97 \\
\hline 8 & 0.8005 & -3.18 & 22 & 0.8352 & 1.01 \\
\hline 9 & 0.8090 & -2.16 & 23 & 0.8287 & 0.23 \\
\hline 10 & 0.8186 & -0.99 & 24 & 0.8242 & -0.32 \\
\hline 11 & 0.8250 & -0.22 & 25 & 0.8228 & -0.49 \\
\hline 12 & 0.8275 & 0.08 & 26 & 0.8244 & -0.30 \\
\hline 13 & 0.8272 & 0.05 & 27 & 0.8283 & 0.18 \\
\hline 14 & 0.8263 & -0.06 & 28 & 0.8291 & 0.27 \\
\hline & & \multicolumn{2}{|c|}{$\begin{array}{l}\text { Top-of-tower displacement }(\mathrm{m}) \text { with no } \\
\text { broken cable }\end{array}$} & 0.8268 & \\
\hline
\end{tabular}


Table 5. Deviation of cable force $(\%)$ resulted from broken cable at different locations of side span.

\begin{tabular}{|c|c|c|c|c|c|c|c|c|c|c|c|c|c|c|c|c|}
\hline \multirow{2}{*}{ Span } & \multirow{2}{*}{$\begin{array}{c}\text { No. of vertical } \\
\text { cable }\end{array}$} & \multirow{2}{*}{$\begin{array}{c}\text { Cable force before } \\
\text { breakage (tf) }\end{array}$} & \multicolumn{14}{|c|}{ No. of broken cable (side span) } \\
\hline & & & 1 & 2 & 3 & 4 & 5 & 6 & 7 & 8 & 9 & 10 & 11 & 12 & 13 & 14 \\
\hline \multirow{15}{*}{$\begin{array}{l}\text { Side } \\
\text { Span }\end{array}$} & 1 & 1750 & & 16.9 & 15.4 & 6.3 & 1.0 & -2.1 & -3.3 & -3.3 & -2.7 & -1.9 & -1.0 & -0.4 & -0.1 & -0.2 \\
\hline & 2 & 723.5 & 36.3 & & 19.6 & 12.1 & 6.7 & 2.4 & -0.4 & -1.8 & -2.3 & -2.0 & -1.4 & -0.7 & -0.3 & -0.2 \\
\hline & 3 & 1047 & 31.1 & 13.5 & & 17.7 & 13.0 & 7.6 & 3.2 & 0.1 & -1.5 & -2.1 & -1.7 & -1.1 & -0.5 & -0.3 \\
\hline & 4 & 953.6 & 27.1 & 10.0 & 21.0 & & 19.2 & 13.9 & 8.0 & 3.2 & -0.0 & -1.7 & -1.9 & -1.3 & -0.6 & -0.3 \\
\hline & 5 & 934.2 & 16.1 & 6.4 & 17.0 & 21.0 & & 20.4 & 14.2 & 7.7 & 2.7 & -0.5 & -1.7 & -1.5 & -0.8 & -0.4 \\
\hline & 6 & 890.2 & 1.2 & 3.2 & 11.9 & 17.2 & 22.8 & & 21.1 & 14.0 & 7.3 & 2.1 & -0.7 & -1.4 & -1.0 & -0.5 \\
\hline & 7 & 841.7 & -8.4 & 0.7 & 6.7 & 11.9 & 18.4 & 22.0 & & 21.7 & 14.2 & 6.8 & 1.6 & -0.7 & -1.0 & -0.5 \\
\hline & 8 & 787.4 & -13.0 & -1.0 & 2.2 & 6.3 & 12.2 & 19.3 & 21.5 & & 21.5 & 14.4 & 6.3 & 1.2 & -0.5 & -0.5 \\
\hline & 9 & 728 & -13.5 & -1.8 & -1.1 & 1.5 & 5.7 & 12.3 & 20.2 & 21.6 & & 21.3 & 14.2 & 5.4 & 1.0 & -0.3 \\
\hline & 10 & 662.8 & -11.2 & -2.0 & -3.0 & -2.0 & 0.3 & 5.0 & 12.3 & 21.5 & 22.3 & & 21.9 & 13.0 & 4.4 & 0.5 \\
\hline & 11 & 587.7 & -7.6 & -1.6 & -3.5 & -3.9 & -3.4 & -0.9 & 4.5 & 12.8 & 23.7 & 24.8 & & 24.2 & 11.0 & 2.2 \\
\hline & 12 & 496.3 & -3.9 & -1.0 & -3.2 & -4.4 & -5.3 & -4.7 & -1.8 & 4.3 & 14.2 & 27.4 & 31.8 & & 22.0 & 5.6 \\
\hline & 13 & 381 & -1.1 & -0.5 & -2.3 & -3.8 & -5.4 & -6.2 & -5.4 & -2.1 & 5.3 & 17.4 & 31.6 & 40.3 & & 11.7 \\
\hline & 14 & 250.5 & 0.4 & -0.1 & -1.3 & -2.4 & -3.7 & -4.9 & -5.4 & -4.3 & -0.4 & 7.7 & 19.3 & 30.0 & 33.5 & \\
\hline & Tower & & & & & & & & & & & & & & & \\
\hline \multirow{14}{*}{$\begin{array}{c}\text { Center } \\
\text { Span }\end{array}$} & 28 & 256.2 & -0.2 & 0.0 & 0.3 & 0.6 & 1.0 & 1.4 & 1.7 & 1.5 & 0.2 & -2.6 & -7.0 & -11.4 & -13.5 & -8.0 \\
\hline & 27 & 381.8 & -1.7 & -0.1 & -0.0 & -0.1 & 0.1 & 0.2 & 0.4 & 0.3 & -0.5 & -2.1 & -4.6 & -7.1 & -8.2 & -5.0 \\
\hline & 26 & 491.3 & -1.8 & -0.0 & -0.2 & -0.4 & -0.6 & -0.6 & -0.5 & -0.5 & -0.9 & -1.6 & -2.6 & -3.5 & -3.9 & -2.5 \\
\hline & 25 & 579.5 & -0.8 & 0.1 & -0.1 & -0.5 & -0.8 & -0.9 & -0.9 & -1.0 & -1.1 & -1.3 & -1.5 & -1.6 & $\begin{array}{l}-1.6 \\
\end{array}$ & -1.0 \\
\hline & 24 & 654.5 & 0.9 & 0.4 & 0.1 & -0.4 & -0.9 & -1.1 & -1.2 & -1.2 & -1.2 & -1.1 & $\begin{array}{l}-1.0 \\
\end{array}$ & -0.7 & -0.5 & -0.4 \\
\hline & 23 & 723.2 & 2.7 & 0.7 & 0.4 & -0.3 & -0.9 & -1.2 & -1.3 & -1.3 & -1.2 & -1.1 & -0.8 & -0.4 & -0.1 & -0.2 \\
\hline & 22 & 789 & 4.4 & 0.9 & 0.6 & -0.2 & -0.9 & -1.2 & -1.4 & -1.3 & -1.3 & -1.1 & -0.7 & -0.3 & 0.0 & -0.1 \\
\hline & 21 & 852.5 & 5.2 & 1.1 & 0.7 & -0.2 & -0.9 & -1.3 & -1.4 & -1.4 & -1.3 & -1.1 & -0.7 & -0.3 & -0.0 & -0.1 \\
\hline & 20 & 911.4 & 4.6 & 1.0 & 0.6 & -0.3 & -0.9 & -1.3 & -1.4 & -1.3 & -1.3 & -1.1 & -0.8 & -0.3 & -0.1 & -0.1 \\
\hline & 19 & 965.5 & 2.1 & 0.6 & 0.3 & -0.4 & -1.0 & -1.2 & -1.3 & -1.3 & -1.2 & -1.1 & -0.8 & -0.4 & -0.1 & -0.2 \\
\hline & 18 & 991.3 & -2.9 & -0.2 & -0.5 & $\begin{array}{r}-0.8 \\
\end{array}$ & -1.1 & $\begin{array}{r}-1.2 \\
\end{array}$ & $\begin{array}{r}-1.2 \\
\end{array}$ & -1.2 & -1.1 & -1.0 & $\begin{array}{l}-0.8 \\
\end{array}$ & -0.4 & -0.2 & -0.2 \\
\hline & 17 & 1087 & -10.8 & -1.3 & -1.5 & -1.2 & -1.1 & -1.1 & -1.0 & -0.9 & -1.0 & -0.9 & -0.7 & -0.4 & -0.2 & -0.2 \\
\hline & 16 & 743.9 & -22.3 & -3.0 & -3.1 & -1.9 & -1.3 & -1.0 & -0.8 & -0.8 & -0.8 & -0.9 & -0.7 & -0.4 & -0.2 & -0.2 \\
\hline & 15 & 1757 & -37.4 & -5.3 & -5.1 & -2.8 & -1.5 & -0.8 & -0.5 & -0.5 & -0.6 & -0.7 & -0.6 & -0.4 & -0.2 & -0.2 \\
\hline
\end{tabular}

Table 6. Deviation of cable force $(\%)$ resulted from broken cable at different locations of center span.

\begin{tabular}{|c|c|c|c|c|c|c|c|c|c|c|c|c|c|c|c|c|}
\hline \multirow{2}{*}{ Span } & \multirow{2}{*}{$\begin{array}{l}\text { No. of vertical } \\
\text { cable }\end{array}$} & \multirow{2}{*}{$\begin{array}{c}\text { Cable force before } \\
\text { breakage (tf) }\end{array}$} & \multicolumn{14}{|c|}{ No. of broken cable (side span) } \\
\hline & & & 28 & 27 & 26 & 25 & 24 & 23 & 22 & 21 & 20 & 19 & 18 & 17 & 16 & 15 \\
\hline \multirow{15}{*}{$\begin{array}{l}\text { Side } \\
\text { Span }\end{array}$} & 1 & 1750 & -0.3 & -0.2 & -2.0 & -1.5 & -1.2 & -1.1 & -1.1 & 0.9 & 0.2 & -0.9 & -2.5 & -5.2 & -5.5 & -31.1 \\
\hline & 2 & 723.5 & -0.3 & -0.2 & -2.1 & -1.6 & -1.3 & -1.2 & -1.4 & 0.5 & -0.1 & -1.1 & -2.3 & -4.3 & -4.2 & -23.2 \\
\hline & 3 & 1047 & -0.4 & -0.3 & -2.1 & -1.6 & -1.4 & -1.4 & -1.7 & 0.2 & -0.5 & -1.2 & -2.2 & -3.4 & -3.0 & -15.6 \\
\hline & 4 & 953.6 & -0.3 & -0.2 & -2.1 & -1.7 & -1.4 & -1.5 & -1.9 & 0.0 & -0.7 & -1.4 & -2.0 & -2.7 & -1.9 & -9.0 \\
\hline & 5 & 934.2 & -0.3 & -0.1 & -2.1 & -1.7 & -1.5 & -1.6 & -2.0 & -0.2 & -0.9 & -1.5 & -1.9 & -2.1 & -1.0 & -4.1 \\
\hline & 6 & 890.2 & -0.3 & $\begin{array}{l}-0.1 \\
\end{array}$ & -2.1 & -1.7 & -1.5 & -1.7 & -2.1 & -0.3 & -1.0 & -1.6 & $\begin{array}{l}-1.7 \\
\end{array}$ & -1.7 & -0.5 & -0.8 \\
\hline & 7 & 841.7 & -0.2 & -0.0 & -2.0 & -1.6 & -1.5 & -1.7 & -2.2 & -0.4 & -1.1 & -1.6 & $\begin{array}{l}-1.7 \\
\end{array}$ & -1.4 & -0.2 & 1.0 \\
\hline & 8 & 787.4 & -0.2 & -0.0 & -2.0 & -1.6 & -1.5 & -1.7 & -2.2 & -0.4 & -1.1 & $\begin{array}{l}-1.6 \\
\end{array}$ & -1.7 & $\begin{array}{l}-1.4 \\
\end{array}$ & -0.1 & 1.5 \\
\hline & 9 & 728 & -0.3 & $\begin{array}{l}-0.1 \\
\end{array}$ & -2.1 & -1.7 & -1.5 & -1.7 & -2.2 & -0.3 & -1.0 & -1.5 & -1.6 & $\begin{array}{l}-1.4 \\
\end{array}$ & -0.2 & 1.1 \\
\hline & 10 & 662.8 & -0.6 & -0.5 & -2.4 & -1.9 & -1.6 & -1.7 & -2.1 & -0.2 & -0.9 & -1.5 & -1.6 & -1.5 & -0.3 & 0.2 \\
\hline & 11 & 587.7 & -1.2 & -1.6 & -3.3 & -2.3 & -1.7 & -1.6 & -1.9 & -0.0 & -0.7 & -1.3 & -1.6 & -1.6 & -0.5 & -0.8 \\
\hline & 12 & 496.3 & -2.6 & -3.9 & -5.0 & -3.2 & -2.0 & -1.4 & -1.4 & 0.4 & -0.4 & -1.0 & -1.4 & -1.5 & -0.6 & -1.5 \\
\hline & 13 & 381 & -5.3 & -8.3 & -8.1 & -4.9 & -2.3 & -0.9 & -0.5 & 1.2 & 0.4 & -0.4 & -0.9 & -1.1 & -0.5 & -1.4 \\
\hline & 14 & 250.5 & -8.5 & $\begin{array}{l}-13.9 \\
\end{array}$ & -11.8 & -6.7 & -2.6 & 0.1 & 1.2 & 2.1 & 1.5 & 0.8 & 0.2 & $\begin{array}{l}-0.1 \\
\end{array}$ & -0.1 & 0.2 \\
\hline & Tower & & & & & & & & & & & & & & & \\
\hline \multirow{5}{*}{$\begin{array}{c}\text { Center } \\
\text { Span }\end{array}$} & 28 & 256.2 & & 32.8 & 27.8 & 16.6 & 6.7 & -0.7 & -4.4 & -5.1 & -4.7 & -3.7 & -2.5 & -1.5 & -0.2 & 0.0 \\
\hline & 27 & 381.8 & 11.9 & & 37.6 & 27.8 & 15.6 & 4.5 & -2.6 & -4.7 & -5.9 & -5.7 & -4.5 & -3.5 & -1.2 & -2.8 \\
\hline & 26 & 491.3 & 5.7 & 22.3 & & 32.9 & 25.2 & 13.1 & 3.4 & $\begin{array}{l}-0.7 \\
\end{array}$ & -4.3 & -5.7 & -5.4 & -4.8 & -1.9 & -5.6 \\
\hline & 25 & 579.5 & 2.1 & 11.2 & 22.5 & & 26.3 & 22.3 & 11.6 & 6.1 & -0.4 & -3.9 & -5.1 & -5.3 & -2.6 & -8.1 \\
\hline & 24 & 654.5 & 0.4 & 4.4 & 11.0 & 22.5 & & 23.6 & 20.0 & 14.4 & 5.6 & -0.2 & -3.2 & \begin{tabular}{|l|}
-4.8 \\
\end{tabular} & -2.8 & -9.6 \\
\hline
\end{tabular}


Table 6. (Continued)

\begin{tabular}{|c|c|c|c|c|c|c|c|c|c|c|c|c|c|c|c|c|}
\hline \multirow{2}{*}{ Span } & \multirow{2}{*}{$\begin{array}{l}\text { No. of vertical } \\
\text { cable }\end{array}$} & \multirow{2}{*}{$\begin{array}{c}\text { Cable force before } \\
\text { breakage (tf) }\end{array}$} & \multicolumn{14}{|c|}{ No. of broken cable (side span) } \\
\hline & & & 28 & 27 & 26 & 25 & 24 & 23 & 22 & 21 & 20 & 19 & 18 & 17 & 16 & 15 \\
\hline \multirow{9}{*}{$\begin{array}{l}\text { Center } \\
\text { Span }\end{array}$} & 23 & 723.2 & -0.4 & 1.0 & 3.5 & 12.0 & 22.0 & & 22.1 & 22.0 & 12.7 & 5.2 & 0.1 & -2.8 & -2.4 & -9.2 \\
\hline & 22 & 789 & -0.6 & -0.5 & -0.5 & 4.7 & 12.8 & 21.0 & & 21.5 & 19.5 & 11.4 & 4.8 & 0.6 & -1.2 & -6.1 \\
\hline & 21 & 852.5 & -0.7 & -1.0 & -2.4 & 0.5 & 5.7 & 12.6 & 19.4 & & 20.4 & 17.3 & 10.1 & 5.1 & 0.8 & 0.1 \\
\hline & 20 & 911.4 & -0.6 & -0.9 & -3.1 & -1.7 & 1.3 & 6.0 & 11.9 & 20.3 & & 20.1 & 15.2 & 10.4 & 3.5 & 9.4 \\
\hline & 19 & 965.5 & -0.5 & $\begin{array}{l}-0.8 \\
\end{array}$ & -3.2 & -2.5 & -1.1 & 1.7 & 5.9 & 14.8 & 19.4 & & 18.9 & 15.6 & 6.8 & 20.5 \\
\hline & 18 & 991.3 & -0.4 & -0.6 & -3.0 & -2.7 & -2.2 & -0.9 & 1.6 & 8.5 & 13.2 & 17.7 & & 19.5 & 10.2 & 22.5 \\
\hline & 17 & 1087 & -0.4 & -0.4 & -2.7 & -2.6 & -2.5 & -2.0 & -0.9 & 4.1 & 7.7 & 12.3 & 16.6 & & 13.2 & 26.0 \\
\hline & 16 & 743.9 & -0.3 & -0.3 & -2.4 & -2.3 & -2.5 & -2.6 & -2.4 & 1.1 & 3.5 & 7.4 & 12.2 & 18.9 & & 31.4 \\
\hline & 15 & 1757 & -0.3 & -0.2 & -2.1 & -2.0 & -2.3 & -2.7 & -3.1 & -0.8 & 0.6 & 3.5 & 8.1 & 15.5 & 14.6 & \\
\hline
\end{tabular}

Table 7. Deviation of total girder stress resulted from broken cable at different locations.

\begin{tabular}{|c|c|c|c|c|c|}
\hline \multicolumn{3}{|c|}{ Side span } & \multicolumn{3}{|c|}{ Center span } \\
\hline $\begin{array}{l}\text { No. of broken } \\
\text { cable }\end{array}$ & $\begin{array}{l}\text { Total stress in girder } \\
\qquad[\sigma]\left(\mathrm{tf} / \mathrm{m}^{2}\right)\end{array}$ & $\begin{array}{c}\text { Deviation of } \\
\text { total girder stress }(\%)\end{array}$ & $\begin{array}{l}\text { No. of broken } \\
\text { cable }\end{array}$ & $\begin{array}{l}\text { Total stress in girder } \\
\qquad[\sigma]\left(\mathrm{tf} / \mathrm{m}^{2}\right)\end{array}$ & $\begin{array}{c}\text { Deviation of } \\
\text { total girder stress }(\%)\end{array}$ \\
\hline 1 & 37555 & 33.56 & 15 & 44492 & 58.23 \\
\hline 2 & 30445 & 8.28 & 16 & 30409 & 8.15 \\
\hline 3 & 33022 & 17.44 & 17 & 32640 & 16.08 \\
\hline 4 & 32859 & 16.86 & 18 & 30625 & 8.91 \\
\hline 5 & 32180 & 14.45 & 19 & 29687 & 5.58 \\
\hline 6 & 30937 & 10.03 & 20 & 29838 & 6.12 \\
\hline 7 & 29824 & 6.07 & 21 & 29983 & 6.63 \\
\hline 8 & 29826 & 6.07 & 22 & 29598 & 5.27 \\
\hline 9 & 29816 & 6.04 & 23 & 29690 & 5.59 \\
\hline 10 & 30494 & 8.45 & 24 & 30332 & 7.87 \\
\hline 11 & 31843 & 13.25 & 25 & 31437 & 11.80 \\
\hline 12 & 33256 & 18.27 & 26 & 32784 & 16.59 \\
\hline 13 & 33980 & 20.85 & 27 & 34942 & 24.27 \\
\hline 14 & 32459 & 15.44 & 28 & 32482 & 15.52 \\
\hline & & \multicolumn{2}{|c|}{$\begin{array}{l}\text { Total stress of girder with no broken } \\
\text { Cable }[\sigma]^{*}\left(\mathrm{tf} / \mathrm{m}^{2}\right)\end{array}$} & 28118 & \\
\hline
\end{tabular}

Table 8. Deviation of total tower stress resulting from broken cable at different locations.

\begin{tabular}{|c|c|c|c|c|c|}
\hline \multicolumn{3}{|c|}{ Side span } & \multicolumn{3}{|c|}{ Center span } \\
\hline $\begin{array}{l}\text { No. of broken } \\
\text { cable }\end{array}$ & $\begin{array}{l}\text { Total stress in tower } \\
{[\sigma]\left(\mathrm{tf} / \mathrm{m}^{2}\right)}\end{array}$ & $\begin{array}{c}\text { Deviation of } \\
\text { total tower stress }(\%)\end{array}$ & $\begin{array}{l}\text { No. of broken } \\
\text { cable }\end{array}$ & $\begin{array}{l}\text { Total stress in tower } \\
{[\sigma]\left(\mathrm{tf} / \mathrm{m}^{2}\right)}\end{array}$ & $\begin{array}{c}\text { Deviation of } \\
\text { total tower stress }(\%)\end{array}$ \\
\hline 1 & 41915 & 60.03 & 15 & 22420 & 14.40 \\
\hline 2 & 28789 & 9.92 & 16 & 25295 & 3.42 \\
\hline 3 & 28465 & 8.68 & 17 & 24989 & 4.59 \\
\hline 4 & 27136 & 3.61 & 18 & 25335 & 3.27 \\
\hline 5 & 26293 & 0.39 & 19 & 25625 & 2.16 \\
\hline 6 & 25780 & -1.57 & 20 & 25945 & 0.94 \\
\hline 7 & 25531 & -2.52 & 21 & 26252 & 0.23 \\
\hline 8 & 25477 & -2.73 & 22 & 25647 & -2.08 \\
\hline 9 & 25507 & -2.61 & 23 & 25789 & -1.54 \\
\hline 10 & 25620 & -2.18 & 24 & 25810 & -1.46 \\
\hline 11 & 25804 & -1.48 & 25 & 25703 & -1.86 \\
\hline 12 & 26019 & -0.66 & 26 & 25492 & -2.67 \\
\hline 13 & 26149 & -0.16 & 27 & 26097 & -0.36 \\
\hline 14 & 26199 & 0.03 & 28 & 26081 & -0.42 \\
\hline & & \multicolumn{2}{|c|}{$\begin{array}{l}\text { Total stress of tower with no broken } \\
\text { Cable }[\sigma]^{*}\left(\mathrm{tf} / \mathrm{m}^{2}\right)\end{array}$} & 26191 & \\
\hline
\end{tabular}


Table 9. Deviation of ultimate load-bearing capacity resulted from broken cable at different locations.

\begin{tabular}{|c|c|c|c|c|c|}
\hline \multicolumn{3}{|c|}{ Side-span } & \multicolumn{3}{|c|}{ Center-span } \\
\hline $\begin{array}{l}\text { No. of broken } \\
\text { cable }\end{array}$ & $\begin{array}{c}\text { Coefficient of ultimate } \\
\text { load-bearing capacity } \\
\text { (with a pair of broken cables) }\end{array}$ & $\begin{array}{c}\text { Decrease of ultimate } \\
\text { load-bearing capacity }(\%)\end{array}$ & $\begin{array}{l}\text { No. of broken } \\
\text { cable }\end{array}$ & $\begin{array}{c}\text { Coefficient of ultimate } \\
\text { load-bearing capacity } \\
\text { (with a pair of broken cables) }\end{array}$ & $\begin{array}{c}\text { Decrease of ultimate } \\
\text { load-bearing capacity }(\%)\end{array}$ \\
\hline 1 & 2.374 & 11.00 & 15 & 2.404 & 9.87 \\
\hline 2 & 2.639 & 1.03 & 16 & 2.628 & 1.47 \\
\hline 3 & 2.596 & 2.65 & 17 & 2.506 & 6.03 \\
\hline 4 & 2.429 & 8.91 & 18 & 2.473 & 7.28 \\
\hline 5 & 2.350 & 11.89 & 19 & 2.400 & 10.02 \\
\hline 6 & 2.304 & 13.60 & 20 & 2.355 & 11.70 \\
\hline 7 & 2.293 & 14.04 & 21 & 2.290 & 14.14 \\
\hline 8 & 2.296 & 13.90 & 22 & 2.307 & 13.51 \\
\hline 9 & 2.296 & 13.92 & 23 & 2.321 & 12.99 \\
\hline 10 & 2.277 & 14.61 & 24 & 2.290 & 14.23 \\
\hline 11 & 2.299 & 13.82 & 25 & 2.329 & 12.67 \\
\hline 12 & 2.334 & 12.47 & 26 & 2.358 & 11.58 \\
\hline 13 & 2.438 & 8.58 & 27 & 2.455 & 7.94 \\
\hline 14 & 2.601 & 2.46 & 28 & 2.624 & 1.60 \\
\hline & & \multicolumn{2}{|c|}{$\begin{array}{l}\text { Ultimate load-bearing capacity with } \\
\text { broken cable }\end{array}$} & 2.667 & \\
\hline
\end{tabular}

(h) There was an about a $60 \%$ increase in total tower stress when the 1st pair of cables broke (see Table 8). This stress is calculated by $[\sigma] *=\frac{P_{z}}{A}+\frac{M_{x} y}{I_{x x}}-\frac{M_{y} x}{I_{y y}}$.

(i) The ultimate load-bearing capacity of the cable-stayed bridge decreased by about $15 \%$ when the 10 th pair of cables neared the center of the side-span broke (see Table 9).

\section{CONCLUSIONS}

Based on the results of the analyses presented above, the following conclusions can be drawn:

(a) When a cable in a cable-stayed bridge breaks, the adjacent cables will experience a significant increase in cable forces. As such, for future cable replacement of the existing cable-stayed bridges, it is crucial to assess the increment of cable force that may occur in the adjacent cables in order to prevent yielding failure in the adjacent cables.

(b) The maximum effects on both the internal force and ultimate load-bearing capacity of a cable-stayed bridge will occur when the outermost cable of the bridge breaks. In addition, the maximum effects on the ultimate loadbearing capacity of the bridge may occur when the cable pairs near the center of the span break. Therefore, when replacing these cables one must assess the effects on the internal force and ultimate load-bearing capacity of the bridge to ensure its safety.

(c) When the outermost cable of a cable-stayed bridge breaks, the tower may undergo a significant horizontal displacement, and the center of the girder may experience significant sagging. It is therefore required that a thorough assessment of the increased displacement be made in advance when replacing the outermost cables, together with proper adjustment of the cable forces in the adjacent cables in order to minimize the increment of displacements for ensuring the bridge safety.

(d) Varying uplifts of the girder of the cable-stayed bridge may occur because of the cable breakage occurring at different locations. This unique characteristic can be used to determine which pair of cables in an existing cablestayed bridge have broken and caused an accompanying uplift of the girder.

\section{REFERENCES}

1. Billington, D. and Hazmy, A., "History and aesthetics of cable-stayed bridges," Journal of the Structural Division, ASCE, Vol. 117, pp. 31013134 (1990).

2. Chang, F. K. and Cohen, E., "Long-span bridges: state-of-the-art," Journal of the Structural Division, ASCE, Vol. 107, pp. 1145-1160 (1981).

3. Ernst, H. J., "Der e-modul von seilen unter beruecksichtigung des durchhanges," Der Bauingenieur, Vol. 40, No. 2, pp. 52-55 (1965).

4. Fleming, J. F., "Nonlinear static analysis of cable-stayed bridges," International Journal of Computers \& Structures, Vol. 10, pp. 621-635 (1979).

5. Gimsing, N. J., Cable Supported Bridges Concept and Design, second edition, John Wiley and Sons, New York (1997).

6. Hegab, H. I. A., "Energy analysis of doubled-plane cable-stayed bridges," Journal of the Structural Division, ASCE, Vol. 113, pp. 2176-2188 (1987).

7. Hegab, H. I. A., "Parametric investigation of cable-stayed bridges," Journal of the Structural Division, ASCE, Vol. 114, pp. 1917-1928 (1988).

8. Lazar, B. E., Troitsky, M. S., and Douglass, M. M., "Load balancing 
analysis of cable-stayed bridges," Journal of the Structural Division, ASCE, Vol. 98, pp. 1725-1740 (1972).

9. Leonhardt, F. and Zellner, W. Past., "Present and future of cable-stayed bridges," Proceedings of the Seminar on Cable-Stayed Bridge Recent Developments and Their Future. Yokohama, Japan, pp. 1-33 (1991).

10. Nazmy, A. S. and Abdel-Ghaffar, A. M., "Three dimensional nonlinear static analysis of cable-stayed bridges," International Journal of Computers \& Structures, Vol. 34, pp. 257-271 (1990).
11. Podolny, W. J. and Scalzi, J. B., Construction Design of Cable-Stayed Bridges, John Wiley and Sons (1976).

12. Tang, M. C., "Analysis of cable-stayed girder bridges," Journal of the Structural Division, ASCE, Vol. 97, pp. 1481-1496 (1971).

13. Tang, M. C., "Design of cable-stayed girder bridges," Journal of the Structural Division, ASCE, Vol. 98, pp. 1789-1802 (1972).

14. Wang, W. T., Cable Replacement of Cable-Stayed Bridges, China Communications Press (1997) 